\title{
PENGARUH PRESTASI PENDIDIKAN AGAMA ISLAM DAN INTENSITAS PENDIDIKAN AGAMA ISLAM DALAM KELUARGA TERHADAP AKHLAK SISWA SMA NEGERI 3 SALATIGA
}

\author{
Ahmad Hasan As'ari ${ }^{1}$, Mustaqhfiroh ${ }^{2}$, Samsul Huda $^{3}$ \\ (IAIN Salatiga, Jl. Lingkar Selatan Salatiga KM. 02, Central Java, Indonesia) \\ Email : ariahmadhasan@gmail.com¹,mustaghfiroh1012@gmail.com², \\ wongbyasabae@gmail.com²
}

\begin{abstract}
This study aims to analyze the effect of Islamic Religious Education Achievement in Schools and the Intensity of Islamic Religious Education in Families Against Student Morals. This type of research is quantitative. This research was conducted at SMA Negeri 3 Salatiga.

The population in this study included all students of SMA Negeri 3 Salatiga, totaling 1,101 students. As for the focus population is only limited to class XI, amounting to 365 students. The sampling technique was a random sampling of 55 students. Retrieval of data used is to use a questionnaire and documentation. The collected data were analyzed using multiple linear regression analysis with the help of SPSS program version 16.0 .

The results showed 1) the achievement of Islamic education in schools in the high category does not have a great effect on the morals of students with a significance level of $0.50 \%$. 2) the intensity of Islamic religious education in families with good criteria has a significantly greater effect of $9.10 \%$. 3) there is a positive and significant influence jointly the achievement of Islamic religious education in schools and the intensity of Islamic religious education in the family on the morals of students in class XI of Salatiga State High School $10.70 \%$ and the remaining $89.30 \%$ is influenced by other factors in outside this research variable.
\end{abstract}

\section{Keywords: Achievement, Family, Islamic and Moral Religious Education.}

\begin{abstract}
ABSTRAK
Penelitian ini bertujuan untuk menganalisis pengaruh Prestasi Pendidikan Agama Islam dalam Sekolah dan Intensitas Pendidikan Agama Islam dalam Keluarga Terhadap Akhlak Siswa. Jenis penelitian ini adalah kuantitatif. Penelitian ini dilakukan di SMA Negeri 3 Salatiga.

Populasi dalam penelitian ini mencakup seluruh siswa SMA Negeri 3 Salatiga yang berjumlah 1.101 siswa. Adapun yang menjadi populasi fokus adalah hanya terbatas pada kelas XI yang berjumlah 365 siswa. Teknik pengambilan sampel adalah dengan random sampling yang berjumlah sebanyak 55 siswa. Pengambilan data yang digunakan adalah dengan menggunakan angket dan dokumentasi. Data yang telah terkumpul dianalisis menggunakan analisis regresi linier berganda dengan bantuan program SPSS versi 16.0.

Hasil penelitian menunjukkan 1) prestasi pendidikan agama Islam dalam sekolah dalam kategori tinggi tidak begitu besar pengaruhnya terhadap akhlak siswa dengan taraf signifikansi 0,50\%.2) intensitas pendidikan agama Islam dalam keluarga dengan kriteria baik memiliki pengaruh yang signifikan lebih besar sebesar 9,10\%. 3) terdapat pengaruh yang positif dan signifikan secara bersama-sama prestasi pendidikan agama Islam dalam sekolah dan intensitas pendidikan agama Islam dalam keluarga terhadap akhlak siswa kelas XI SMA Negeri 3 Salatiga sebesar 10,70\% dan sisanya 89,30\% dipengaruhi oleh faktor-faktor lain di luar variabel penelitian ini.
\end{abstract}

Kata Kunci: Prestasi, Keluarga, Pendidikan Agama Islam dan Akhlak. 


\section{A. PELIMINARY}

Islam regulates the social, economic, political, cultural and educational aspects of human life. The significance of education is a focal point in Islamic teachings. Islam places education in a very vital position. The indication is very clear as emphasized in the Q.S. Al-'Alaq: 1-5 states:

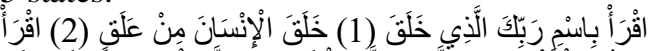

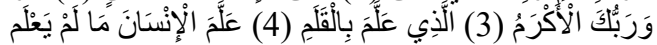

Artinya : "Read in the name of your Lord

Who Created, He Created man from a clot of blood. Read, and it is your Lord who is most gracious, Who teaches (man) by means of kalam, He teaches man what he does not know."(Soenarjo dkk, 2005: 597)

Law Number 20 of 2003 on the National System in Chapter I Paragraph 1 states that:

Education is a conscious and planned effort to create an atmosphere of learning and the process of students so that students actively develop their potential to have religious spiritual strength, self-control, personality, intelligence, noble character, and skills needed by themselves, society, nation and state. (UU RI No. 20, 2003: 9)

Education is a conscious and planned effort to create an atmosphere of learning and the process of students so that students actively develop their potential to have religious spiritual strength, self-control, personality, intelligence, noble character, and skills needed by themselves, society, nation and state.

Education in the concept of Islam, must be able to achieve two things. First, to encourage people to know their God so that they are aware of worshiping Him with confidence, carrying out the required rituals and obeying the Shari'ah and divine provisions. Second, encourage people to understand the sunnah of Allah in this universe, investigate the earth and use it to protect their faith and religion. (Noor Rohani, 2010: 18)

Islamic religious education is education through the teachings of the Islamic religion, namely efforts in the form of guidance and care for students so that later after completing education they can understand, appreciate and practice the teachings of Islam that they believe in as a whole. As well as making Islamic teachings as a view of life for the safety and welfare of life in the world and in the hereafter. (Q.S. al-Baqarah/2: 201)

The first environment in Islamic education is the family environment. In the family environment, parents determine the pattern of first coaching for their children. Islamic teachings emphasize that every human being can take care of his family from the dangers of the torment of hellfire, also includes protecting children and property so that they do not become slander, namely by educating the children as well as possible. So through education of children in particular, parents will avoid the danger of slander and avoid the danger of the torment of hellfire.

According to Ibn Qayyim, quoted by Marzuki that responsibility for children, especially in terms of education, rests with parents and educators. Children really need guidance and qudwah that can be used as role models for him. Therefore, education in the family environment, what parents must start is to try to educate their children well, and instill quranic values from an early age. This is intended so that at adulthood the child will be imprinted on the teaching values contained in Islam.

Parents who have never instilled religious understanding in their children will shape their children away from religion (secular). Parents who only provide material needs to their children will produce materialistic and hedonistic children. No wonder so many nation's children are smart and graduates of well-known educational institutions but have a corrupt spirit.(Q.S. At-Tahrim/66:6) This includes several negative impacts that can be felt with the naked eye for parents who are reluctant to choose and make religious values one of the choices of parenting in fostering family members.

Besides being in the family, the school environment also has a very urgent role in fostering cognitive, affective, and psychomotor intelligence of students. According to Asrorun Ni'am, school education is a means of shaping human beings with religious-ethical characteristics.(Q.S. Al-Kahfi/18: 46) However, in reality it is known that students who receive high religious education scores do not automatically have the morals displayed in daily life in line with what is reported in the report cards. (Interview with PAI teacher at SMA Negeri 3 Salatiga, Monday, July 15 2019)

According to Rachman, modern adolescents now have a tendency and are permissive towards premarital sex. (M. Fauzi Rachman, 2012: 29) Then a survey conducted by the National Commission for Child Protection in January - June 2010 in major cities in Indonesia involving 4500 junior and secondary school students showed that 62.75 female students were no longer virgins. (Dian Ningrum, 2018: 
30) Of course this phenomenon is very worrying because it is on the shoulders of these teenagers that our hopes are pinned to teenagers as the nation's next generation, and that hope will fade when teenagers fall into promiscuity and free sex.

Whereas in the Koran itself it has been explained and emphasized so that humans do not only compete in achieving very high scores but more than that, namely competing in continuously trying to be good where, towards anyone, in time and any condition. This is as in QS. Al-Baqarah / 2: 148.

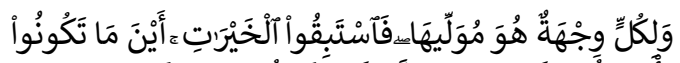

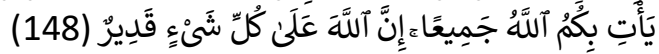
Meaning: And every people has a qibla that he faces towards Him. So compete with you in goodness. Wherever you are, Allah will gather you all. Indeed, Allah has power over all things. (Syaamil Al-Qur'an, 2007: 23)

Problems such as the one above are due to the assessment system reported by the majority of teachers is still based on cognitive assessment alone and not fully based on affective assessment. (Interview with PAI teacher at SMA Negeri 3 Salatiga, Monday, July 15 2019)

As Abdullah Idi said, Islamic Education of students is said to be successful if their personality has been engraved with a high awareness and responsibility both to the Creator-Allah, fellow human beings, and their environment. (Abdullah Idi dan Safarina Hd, 2016:17)

Effect of Islamic religious education in the family on the religious attitudes of students at Madrasah Aliyah Darunnajah Botong Kec. Bungaya Kab, Gowa there are personality competencies possessed by Islamic religious education teachers and families, students can learn effectively and in a conducive atmosphere, be kind to Islamic religious education teachers and parents, students are able to receive lessons well so that students can add to their knowledge especially in Islamic religious education subjects that affect the morals and behavior of students in the family. The three journals written by Adi Rosadi The results of the study were the reality of the praiseworthy behavior of positive students, it was obtained that the average calculation value $=3.94$, this figure is in the high category, because it is in the range of values 3.5-4.5. While the reality of student achievement is 84.02, this shows that the qualification is very good because it is in the 80100 interval. As for the relationship between the two, namely the influence of behavior

Praiseworthy students for learning achievement in the subject of Islamic Religious Education has a moderate category with a value of 0.46 in the range $0.40-0.70$. As for the value of $\mathrm{t}$ arithmetic $=3.96$ is greater than table $=$ 1.67 states that the null hypothesis which states there is no effect of students' commendable behavior on learning achievement in Islamic Religious Education subjects is rejected. The correlation coefficient number has an influence level of $11 \%$.

From several previous studies, the difference with the research that the author wrote is that it lies in the morals of the students. Then the aspects of this research are consisted of; 1) Moral towards Allah, 2) Moral towards humans, 3) Moral towards the surrounding environment, 4) Moral towards oneself, and 5) Moral towards parents.( Moh. Ardani, 2005: 55)

\section{B. RESEARCH OBJECTIVES}

From the description above, several research objectives can be proposed as below:

1. Do you know the extent to which the influence of Islamic religious education achievements on morals in SMA $\mathrm{N} 3$ Salatiga students in the 2019/2020 school year?

2. Do you know the extent of the influence of the intensity of Islamic religious education in the family on morals for SMA N 3 Salatiga students in the 2019/2020 academic year?

3. Do you know the extent of the influence of the achievement of Islamic religious education and the intensity of Islamic religious education in the family on morals in SMA N 3 Salatiga students in the 2019/2020 school year?

\section{RESEARCH METHOD}

This type of research is a type of quantitative research. While the approach used in this study is a type of multiple linear regression analysis approach. This analysis is used to determine the direction of the relationship between the independent variable (X1, X2) and the dependent variable (Y) whether each independent variable is positively or negatively related and to predict the value of the dependent variable if the value of the independent variable has increased or decreased. The data used is usually an interval or ratio scale.

In retrieving data, the researcher used two methods or steps, namely a questionnaire and documentation. First, the questionnaire, in the questionnaire, the questions are arranged in the form of an interrogative sentence, while in the questionnaire, the questions are arranged in a statement sentence with the available answer options. Then a questionnaire was distributed to respondents to find out about two variables, 
namely the intensity of Islamic religious education in the family and student morals.

Second, documentation, is the taking of data and images during research and all archives or records that come from school which are then arranged regularly and systematically in research reports. The documentation required is the result of semester I grades as in the following table:

\begin{tabular}{|c|l|l|}
\hline NO & \multicolumn{1}{|c|}{ STATEMENT } & \multicolumn{1}{|c|}{$\begin{array}{c}\text { Documentation } \\
\text { Data }\end{array}$} \\
\hline $\mathbf{1}$ & $\begin{array}{l}\text { The value of the PAI } \\
\text { subject knowledge I } \\
\text { obtained in the first } \\
\text { semester report card }\end{array}$ & \\
\hline $\mathbf{2}$ & $\begin{array}{l}\text { The skills value of } \\
\text { Islamic Education } \\
\text { subjects that I } \\
\text { obtained in the first } \\
\text { semester report cards. }\end{array}$ \\
\hline $\mathbf{3}$ & $\begin{array}{l}\text { The attitude value of } \\
\text { Islamic Education } \\
\text { subjects that I } \\
\text { obtained in the first } \\
\text { semester report cards. }\end{array}$ \\
\hline$*$ & total & \\
\hline
\end{tabular}

Data collected have been analyzed using descriptive analytic methods and inferential statistical analysis. With analytical descriptive analysis techniques are used for qualitative and quantitative data, meaning that it is only limited to the description of the data that has been successfully collected in the study.

The data obtained from this study are then processed and analyzed to answer the formulated problems and research hypotheses. The data collected were analyzed in two stages, namely preliminary analysis and further analysis.

Preliminary analysis for the variables of Islamic religious education achievement in schools, the intensity of Islamic religious education in the family and student morals includes frequency distribution in the form of categorization, mean (average) and appearance of data in the form of histograms.

Further analysis was used to test all three hypotheses. To analyze the relationship between the independent variables (Islamic religious education in schools and the intensity of Islamic religious education in the family) with the dependent variable (student morals), this study used a multiple linear regression formula.

\section{RESULTS AND DISCUSSION}

In the large Indonesian dictionary, learning achievement is the mastery of skills or knowledge developed by subjects, usually indicated by test scores or numerical scores given by the teacher. According to Ahmad Susanto, what is meant by learning achievement is an ability that a child gets after going through learning activities. Based on the definition, learning achievement is the result that is given by teacher to students, after do learning process in the school.

Masruri quoted Benjamin S. Bloom in his thesis quoted by Abu Muhammad Ibnu Abdullah as well stated that types, indicators and learning outcomes can be classified into three domains, they are: a) cognitive, b) affective, and c) the psychomotor.

Regarding to the three taxonomic domains, Nana Sudjana gare simple and acceptable explanation. First cognitive domain, is related to intellectual or thinking aspects, it includes of knowledge, understanding, application, analysis, synthesis and evaluation. . Second, affective domains is related to emotional aspects, such us feelings, attitudes, moral, compliance and so on. It including attending, responding, giving value, organizing, and characterizing. (characterization). The last is psychomotor domains. It is related to skill aspects that involve nerve, muscle and psychicfunctions, inclusive of adaptation and origination.

Based on the explanation above, it can be said that student achievement must cover at least three things consisting of aspects of the knowledge, skills and attitudes of the students themselves.

Islamic Religious Education is a conscious effort to prepare students to believe, understand, live and practice the Islamic religion through teaching guidance activities or training to pay attention to the demands of respecting other religions in the relationship of harmony between religious communities in society to realize national unity.

According to Sayyid Sabiq the aim of Islamic religious education is so that one's soul can be perfectly educated, so that someone can fulfill his obligations because Allah SWT, can strive for the benefit of the family, the interests of the community, and can be honest, have the right side, and wish to develop seeds happiness in humans.

The scope of Islamic religious education includes harmony, harmony, and balance between human relations with Allah SWT, human relations with fellow humans, human relations with oneself, human relations with other creatures and their environment. Meanwhile, the scope of Islamic education in schools includes elements consisting of aspects of faith, worship, al-Qur'an, mu'amalah, syari'ah and dates. 
a. The main content and material of the Islamic religious education curriculum have different characteristics from other education, the characteristics of the Islamic Education curriculum in question are:

b. The PAI curriculum must be prominent in religious subjects (worship, muamalah, syari'ah), religion must be taken in the alQur'an, hadiths and wrong previous examples.

c. The PAI curriculum will pay attention to the overall development of students' personal aspects, namely body, mind and spirit.

d. The PAI curriculum pays attention to the balance between the person and society, the world and the hereafter, the body and the spirit and the human mind.

e. The PAI curriculum also pays attention to arts and culture in society. (Sayyid Syabiq, 1981: 153)

Thus it can be said that what is meant by the achievement of Islamic religious education in schools is the result of efforts made by Islamic religious education teachers after going through guidance, teaching or training activities to prepare students to believe, understand, live and practice the teachings of Islam in a truly full way. awareness that is manifested in the form of an assessment report card at the end of each lesson. So that in this study to obtain variable data on the achievement of Islamic religious education in schools, researchers only need to read student report cards obtained from the subject teacher of Islamic religious education at SMA N 3 Salatiga.

Then from the report cards the researchers recap, move, sort and put them into several categories; very low, low, high, very high as in the prepared questionnaire table. As for the variable aspects of the achievement of Islamic religious education in schools consist of; 1) the average value of students' knowledge, 2) the average value of students' skills, and 3) the average value of students' attitudes.

Intensity is ability or strength, persistence or strength. (Partanto, 265) In the Psychology dictionary is the strength of behavior or experience, or attitudes that are maintained. (Ashari M. Hafi, 1996:297) Whereas in the Big Indonesian Dictionary, intensity means a state of intense level or measure. (Departemen Pendidikan Indonesia, 2003: 383)

From the explanation of the meaning of the intensity, it can be said that what is meant by intensity is the level of one's attention to something that is wanted to be maintained in order to obtain the desired goal. For example, the intensity of parents towards Islamic religious education of their family members.
The family is a unit consisting of a husband and a wife, or in other words, the family is a continuous association between a man and a woman where one feels at ease with the other according to what is determined by religion and society. When a husband and wife are blessed with one or more children, those children become the third main element in the family in addition to the two previous elements. ". (Hasan Langgulung, 1996: 346)

Zuhairi et al argue that Islamic education is an effort directed at forming a child's personality in accordance with Islamic teachings or an effort with Islamic teachings, thinking, deciding and acting based on Islamic values, and being responsible according to Islamic values.

Muhammad Fadhil defines Islamic education as an effort to develop, encourage and invite students to live more dynamically based on high values and noble lives. With this process, it is hoped that a perfect student's personality will be formed, whether related to the potential for reason, feeling, or action. Meanwhile, according to Ahmad Tafsir, Islamic education is guidance given by a person to a person so that they develop optimally in accordance with Islamic teachings.

From the definition of the experts above, it can be concluded that Islamic religious education is an effort to develop all human potential to the maximum in accordance with the teachings of Islam in order to become a perfect Muslim.

A family that is built on the basis of religion through a marriage process whose members have the ability and responsibility to create peace through good association with the division of tasks according to their position, status and function as family members so that they become a back and shelter for their members and the base of community strength to gain peace of life. (Mantep Miharso, 2004:40)

To obtain peace of life among family members, a synergistic climate must be created. So it is necessary to know some of the characteristics that must be possessed by parents as a leader in the family, namely physical and mental energy, awareness of the purpose and direction of children's education, enthusiasm, harmony and love, personality integrity, technical mastery of educating children, assertiveness in making decisions, smart, confident, objective, and have a personal drive. (Syaiful Bahri Djamarah, 2004: 27)

Thus it can be said that a family that applies Islamic religious values as a model of education in family members will produce a life full of peace and love, so that in the end all the positive 
potentials that exist in all members will develop to the maximum.

From the description above, it can be concluded that what is meant by the intensity of Islamic religious education in the family in this study is the attention of parents to their children on the values of Islamic religious education which is always emphasized, applied and maintained in everyday life. As for the aspects of the variable intensity of Islamic religious education in the family consist of; 1) aspects of basic / obligatory worship ('ubudiyah mahdhoh), 2) aspects of supporting worship (" ubudiyah ghoiru mahdhoh), and 3) aspects of reading daily prayers.

The word morality comes from the Arabic language which has become Indonesian, and is the plural of the word khuluq, which means behavior, budi pekrti, tingkah-laku or tabi'at. (Ahmad Warson Munawwir, 2002: 364) Morals are likened to decency, courtesy. (A. Mustofa, 1997: 11) Whereas the word khuluq is a description of human inner nature, a description of the outward form of human beings such as the facial expressions of limbs and the whole body. Khuluq is equated with the word ethicos or ethos which means customs, the inner feeling of the heart's tendency to do actions. ( $\mathrm{M}$. Yatimin Abdullah, 2007: 2)

Nasiruddin in Tasawuf Education, khuluq is the opposite of khalq, in which khuluq is an invisible thing while khalq is a visible form (creation). Khalq is seen with the physical eye (bashar) while the khuluq is seen with the inner eye (bashirah). Both words come from the word khalaqa which means creation. (Mohammad Nasirudin, 2009: 31)

As for the terminology, experts have defined morals, the following is the explanation:

Imam Ghazali defined khuluq or morals as a trait that is embedded in the soul from which easy actions arise, with no need for thought and consideration if that attitude appears in the form of good and praiseworthy deeds according to reason and syari'at. (Abu Hamid Muhammad bin Muhammad al-Ghazali: 58) Meanwhile, according to Ibn Maskawaih, it is the mental state of a person that encourages him to perform actions without going through thoughts and considerations. (Ibn Miskawaih, 1985: 25)

According to Hasan Langgulung, morals are habits or attitudes that are deep in the soul from which actions appear easily, which in their formation depend on hereditary and environmental factors. (Hasan Langgulung, 2003: 58)

According to Zakiah Daradjat, morals are inner strength which is the best means of selfcontrol, it regulates behavior, speech and attitude, is a driving force that works regularly, continuously and regularly. Meanwhile, Abuddin Nata provides the meaning of the substance of the term moral action into five parts. First, moral actions are actions that have been deeply embedded in a person's soul, so that they have become his personality. Second, moral deeds are actions that are carried out easily without thought. Third, moral deeds are actions that arise from within the person doing it, without any coercion or pressure from outside. Fourth, moral actions are actions that are actually done not playing games or because of acting. Fifth, moral actions are good deeds that are done out of sincerity solely because of Allah, not because people want to be praised or because they want to get something praised. (Abuddin Nata, 2014: 4)

From some of the above opinions it can be concluded that morals are actions that arise spontaneously as a reflection of the state of the soul and are also qualities of human actions that arise from within, not coercion from without, where these behaviors have good qualities and some are bad, right and incorrectly conform to certain measures of community and environmental action.

Apart from the word morals, there are other terms that are almost the same, namely behavior. The word behavior means individual responses or reactions to stimuli or the environment that are manifested in movement (attitude), not just body or speech. (Dekdikbud, 1993: 671) According to Gordon Allport who was quoted by Saefudin Azwar as saying behavior is the readiness to react to an object in certain ways and it can be said that the intended readiness is a potential tendency to react in a certain way when the individual is faced with a stimulus that requires a response. (Saefudin Azwar, 1995: 5) Behavior emphasizes more on reactions in the form of motion

manifested in the form of all one's observable activities. (Hasan Langgulung, 1995: 139)

Meanwhile, according to the researcher, Islamic behavior is a unity of actions carried out by a human being based on religion that is carried out in everyday life both in relation to Allah SWT, fellow Muslims, and with their environment in accordance with the teachings of the Qur'an and Hadith, both in terms of Worship, and social aspects that cover cognitive, affective and psychomotor aspects.

Thus, it can be said that what is meant by the morals of students is any act or speech done by students that is related to Islamic religious values, all done because of the belief in God with the teachings that have been accepted and understood. Then the aspects of the moral variables in this study consist of; 1) Moral 
towards Allah, 2) Moral towards humans, 3) Moral towards the surrounding environment, 4) Moral towards oneself, and 5) Moral towards parents. (Moh. Ardani, 2005: 55)

This research was conducted on the 10th grade students of SMA Negeri 3 Salatiga. The research data was taken using a questionnaire that had been tested for validity and reliability for each instrument. The collection of data on the achievement of Islamic religious education instruments in schools was taken from the value of report cards that had been documented by teachers of Islamic religious education subjects and character. The variables in this study consisted of the achievement of Islamic religious education in schools (X1), the intensity of Islamic religious education in the family (X2), and student morals (Y), with the following data variations:

Table 4.1

Results of the Analysis of Research Variables Descriptive Statistic

\begin{tabular}{|l|c|c|c|c|c|}
\hline & N & Min & Max & Mean & $\begin{array}{c}\text { Std. } \\
\text { Dev } \\
\text { iati } \\
\text { on }\end{array}$ \\
\hline $\begin{array}{l}\text { PAI } \\
\text { achieve } \\
\text { ment in } \\
\text { school }\end{array}$ & 55 & 72.00 & 89.00 & 83.20 & 3.67 \\
\hline $\begin{array}{l}\text { The } \\
\text { intensity } \\
\text { of PAI } \\
\text { in the } \\
\text { family }\end{array}$ & 55 & 32.00 & 72.00 & 56.20 & 8.79 \\
\hline $\begin{array}{l}\text { Student } \\
\text { morals }\end{array}$ & 55 & 101.00 & 135.00 & 1.19 & 9.12 \\
\hline $\begin{array}{l}\text { Valid N } \\
\text { (listwise) }\end{array}$ & 55 & & & & \\
\hline
\end{tabular}

Based on table 4.1, we can explained that the variable of Islamic religious education achievment (X1) has mean 83.20 with 3.67 deviation standard. Islamic education intensity in the family (X2) has mean of 56.20 with 8.79 and a student moral variable (Y) has mean of 119.02 with 9.12 deviation standard. For the detail, please find each frequency of variable as follows:

Achievements of Islamic Religious Education in Schools (X1)

The following is a description of the achievement data of Islamic religious education in schools for class XI students of SMA Negeri 3 Salatiga based on the score criteria:

Table 4.2

Description of Islamic Education Achievement in Schools

\begin{tabular}{|c|c|c|c|c|}
\hline No & Interval & Criteria & Frekuensi & Percentage \\
\hline & & Good & & \\
\hline 2 & $76-85$ & Good & 39 & $70,90 \%$ \\
\hline 3 & $66-75$ & Enough & 2 & $3,60 \%$ \\
\hline 4 & $<50-65$ & $\begin{array}{c}\text { Not } \\
\text { Good }\end{array}$ & 0 & $0 \%$ \\
\hline & Total & & 55 & $100 \%$ \\
\hline
\end{tabular}

Based on Table 4.1 it can be explained that the intensity of Islamic religious education in schools is known to have very good criteria of student achievement of $25.40 \%$, good $70.90 \%$, enough $3.60 \%$ and not good $0 \%$. Meanwhile, the mean obtained is 83.20 which is located at the interval 76-85 in the high category. Thus it can be stated that the achievements of Islamic education that have been achieved by class XI students of SMA Negeri 3 Salatiga are included in good criteria.

1.Variable Intensity of Religious Education in Families (X2)

The variable of religious education intensity in the research instrument family consisted of 20 questions with 4 answer choices. The following is a description of the data on the intensity of religious education in families based on the scoring criteria:

Tabel 4.3

Description of the Intensity of Religious Education in the Family

\begin{tabular}{|c|c|c|c|c|}
\hline No & Interval & Criteria & Frekuensi & Percentage \\
\hline 1 & $66-80$ & $\begin{array}{c}\text { Very } \\
\text { High }\end{array}$ & 5 & $9,00 \%$ \\
\hline 2 & $51-65$ & High & 38 & $69,00 \%$ \\
\hline 3 & $36-50$ & Low & 11 & $20 \%$ \\
\hline 4 & $21-35$ & $\begin{array}{c}\text { Very } \\
\text { Low }\end{array}$ & 1 & $1,80 \%$ \\
\hline & Total & & 55 & $100 \%$ \\
\hline
\end{tabular}

Based on Table 4.3, it can be explained that the criteria for Islamic religious education in the family are very high $9.00 \%$, high $69.00 \%$, low $20 \%$ and very low $1.80 \%$. Meanwhile, the mean obtained is 56.20 which lies at the interval 5165 in the good category. Thus it can be stated that the intensity of Islamic religious education carried out by parents of class XI SMA Negeri 3 Salatiga is included in the high criteria.

1. Student's Moral Variable (Y)

The students' moral variables were 38 questions with 4 answer choices. The following is a description of the student's moral data based on the scoring criteria:

Table 4.4

Description of Student Morals

\begin{tabular}{||c|c|c|c|c|}
\hline No & Interval & Criteria & Frekuensi & $\begin{array}{c}\text { Percen } \\
\text { tage }\end{array}$ \\
\hline 1 & $\begin{array}{c}125- \\
152\end{array}$ & $\begin{array}{c}\text { Very } \\
\text { Good }\end{array}$ & 16 & $29,00 \%$ \\
\hline
\end{tabular}




\begin{tabular}{|c|c|c|c|c|}
\hline No & Interval & Criteria & Frekuensi & $\begin{array}{c}\text { Percen } \\
\text { tage }\end{array}$ \\
\hline 2 & $97-124$ & Good & 39 & $70,90 \%$ \\
\hline 3 & $67-96$ & Enough & 0 & $0 \%$ \\
\hline 4 & $40-68$ & $\begin{array}{c}\text { Not } \\
\text { Good }\end{array}$ & 0 & $0 \%$ \\
\hline & Total & & 55 & $100 \%$ \\
\hline
\end{tabular}

Based on Table 4.4 it can be explained that the morals of XI grade students of SMA Negeri 3 Salatiga are known to be in very good criteria $29.00 \%, 70.90 \%$ good, $0 \%$ enough and $0 \%$ less good. Meanwhile, the mean obtained is 119.02 which lies in the interval 97-124 in the good category. Thus it can be stated that the morals reflected by the students of class XI SMA Negeri 3 Salatiga are in the good category.

The description analysis results show that the achievement of Islamic education in schools obtained by Salatiga State High School 3 students in 2019/2020 included in the high category obtained a mean of 83.20 located at intervals of $76-85$ with a percentage of $70.90 \%$. There is no effect of the achievement of Islamic religious education in schools on student morals by $0.50 \%$.

The above shows that the achievements of Islamic religious education in schools obtained by Salatiga State High School 3 students did not have a significant impact on student morals, as the results of the regression analysis on the achievements of Islamic religious education in schools were positive and significant. If the achievement of Islamic religious education in student schools is getting better, then the students' morals will be better.

The results of analysis description show that Islamic education interisty in the family from SMA N 3 Salatiga in the academis year $2019 / 2020$ is good since the mean is 56.20, located intervals of 51-65 with a percentage of $69.00 \%$. This percentage is same with Islamic education achievement in the schools which is contribute $0.50 \%$ to student morals. There is no influence of Islamic education interisty in the family of $9.10 \%$. It should that the intensity of Islamic education in family gives bigger contribution to student than the contribution in the schools. The influence of Islamic education family shows a positive and significant regression.

Based on the research and hypothesis testing above, the proof is there is a positive and significant influence on Islamic education achievement in the schools (X1), the intensity of Islamic education in the family (X2) on the students' morals (Y). Islamic education achievment in the school contribution $0.50 \%$, it means in case the achievement of Islamic education in school is higher, the students' moral will be better. The intensity of Islamic education in the family towards the student morals gives contribution $9.10 \%$. It means that in case the intensity of Islamic education activities at home is increased, the students' morals will increased as well.

The results of hypotheses test about Islamic education intensity in the schools and family show a significant and positive effect. The proof is results of data processing which show of $10.70 \%$. The same positive regression of Islamic education achievement in the schools and family show that as long as the student get good achievement in the school and Islamic education from that family, the student's morals will be better.

\section{CLOSING}

\section{Conclusion}

a. The effect of the achievement of Islamic religious education on morals in SMA N 3 Salatiga students in the 2019/2020 school year is very low. This can be seen from the results of the descriptive analysis of variations in research data in class XI SMA Negeri 3 Salatiga, the variable of Islamic religious education achievement in school (X1) is in the high category, the mean is 83.20 which is located in the 7685 interval with a percentage of $70.90 . \%$. There is no effect of the achievement of Islamic religious education in schools on student morals by $0.50 \%$. In other words, the achievement of Islamic religious education does not significantly influence students' moral behavior.

b. The influence of the intensity of Islamic religious education in the family on morals in SMA N 3 Salatiga students in the $2019 / 2020$ school year the intensity variable of Islamic religious education in the family (X2) is included in the good category, the mean is 56.20 which is located at intervals of 51-65 with a percentage of $69,00 \%$. This percentage is in line with the achievement of Islamic religious education in schools which both contribute $0.50 \%$ to student morals. There is no influence on the intensity of Islamic religious education in the family of $9.10 \%$. This shows that the intensity of Islamic religious education in the family provides a greater contribution to student morals than the achievement of Islamic religious education in schools. The influence of the intensity of Islamic religious education in the family on student morals shows a positive and significant regression coefficient. 
c. The effect of the achievement of Islamic religious education and the intensity of Islamic religious education in the family on morals in SMA N 3 Salatiga in the 2019/2020 academic year, it can be concluded that there is a positive and significant influence together between the achievement of Islamic religious education in schools and intensity. Islamic religious education in the family towards the morals of class XI SMA Negeri 3 Salatiga is $10.70 \%$ and the remaining $89.30 \%$ is influenced by other factors outside of this research variable.

2. Suggestion

After the researcher finished, he conducted a study of 3 Salatiga State High School students related to students' moral issues related to the achievements and intensity of Islamic education both in schools and families. The researcher will provide several suggestions to several parties:

a.To school managers, the school should be together and unified in implementing values that reflect Islamic religious education with the existence of a program of habituation and the existence of rolemodels from the teachers and staff.

b.Dear students, develop your talents and skills and don't leave learning and practicing the value of Islamic religious education in your daily life, both at home, school and outside of these two places.

c. To both parents, they should continue to carry out harmonious supervision in instilling the value of Islamic religious education in a family that fathers / mothers develop patiently, sincerely, consistently and provide role models for children regarding the practice of various aspects of Islamic teachings.

\section{Daftar Pustaka}

A. Mustofa, Akhlak Tasawuf, Bandung: Pustaka Setia, 1997.

Abdullah Idi dan Safarina Hd., Etika Pendidikan Keluarga, Sekolah dan Masyarakat, Jakarta: RajaGrafindo Persada, 2016.

Abu Hamid Muhammad bin Muhammad al-Ghazli, Ihya' 'Ulum al-Din Jilid III, Beirut: Dar al-Kutub.

Abuddin Nata, Aklak Tasawuf dan Karakter Mulia, Jakarta: Raja Grafindo Persaja, 2014.

Ardani, Moh., Akhlak Tasawuf: Nilai-Nilai Akhlak/Budi Pekerti dalam Ibadat \& Tasawuf, Jakarta: CV. Karya Mulia, 2005.

Ashari M. Hafi, Kamus Psychology, Surabaya: Usaha Nasional, 1996.
Dekdikbud, Kamus Besar Bahasa Indonesi, Jakarta: Balai pustaka, 1993.

Departemen Pendidikan Indonesia, Kamus Besar Bahasa Indonesia, Jakarta: Balai Pustaka, 2003.

Dian Ningrum, "Kemerosotan Moral di Kalangan Remaja: Sebuah Penelitian Mengenai Parenting Style dan Pengajaran Adab", Jurnal UNISIA, Volume 37, Nomor 82, (Juni 2018), 18-30.

Ibn Miskawaih, Tahdzib al-Akhlak Fii al-Tarbiyah, Beirut : Dar al-Kutub al-Ilmiyah, 1985.

Langgulung, Hasan. Beberapa Pemikiran Tentang Pendidikan Islam, Bandung: PT ALMa'Arif, 1993.

M. Fauzi Rachman, Islamic Teen Parenting, Jakarta: Erlangga, 2012, 29.

M. Yatimin Abdullah, Studi Akhlak dalam Perspektif Al-Qur'an, Jakarta: Amzah, 2007.

Masruri, "Pengaruh Perhatian orang tua dan motivasi belajar siswa terhadap prestasi belajar pendidikan agama Islam siswa SMK Islam Pemalang" Tesis,8.

Miharso, Mantep. Pendidikan Keluarga Qur'ani, Yogyakarta: Saiiria Insania Press, 2004.

Mohammad Nasirudin, Pendidikan Tasawuf, Semarang: RaSAIL Media Group, 2009.

Munawwir, Ahmad Warson. Kamus Al-Munawwir; Arab-Indonesia Terlengkap, Surabaya: Pustaka Progessif, 2002.

Noor, Rohani M. KH Hasyim Asy'ari Memodernisasi NU \& Pendidikan, Jakarta: Grafindo Khazanah Ilmu, 2010.

Partanto, dkk, Kamus Ilmiah Populer, Surabaya: Arloka, tanpa tahun.

Safrina Hd., Abdullah Idi dan. Etika Pendidikan Keluarga, Sekolah dan Masyarakat, Jakarta: RajaGrafindo Persada, 2016.

Soenarjo, dkk, Al-Qur'an dan Terjemahannya, Kudus: Menara Kudus, 2005.

Syaamil Al-Qur'an, Al-Qur'an Terjemahan PerKata, Jakarta: Sygma, 2007, 23.

Wawancara dengan guru PAI SMA Negeri 3 Salatiga, Senin, 15 Juli 2019.

Zakiah Daradjat, Pendidikan Islam dalam Keluarga dan Sekolah, Jakarta: Ruhama, 1995. 